\title{
INFLUENCE OF SOIL TILLAGE SYSTEM, FERTILIZER AND TREATMENT APPLIED TO SEEDS ON SOYBEAN CHEMICAL COMPOSITION
}

\author{
Camelia Urdă $\breve{l}^{l}$,Loredana Suciu ${ }^{1,2}$, Felicia Mureșanu ${ }^{l}$, Luana Păcurar ${ }^{l}$, Nicolae Tritean ${ }^{l}$, \\ Adrian Negrea ${ }^{1}$, Ioana Crişan ${ }^{1}$, Raluca Rezi ${ }^{l}$, Florin Russu ${ }^{1}$, Adina Tărău ${ }^{1, *}$ \\ ${ }^{1}$ Research and Development Station for Agriculture Turda \\ ${ }^{2}$ University of Agricultural Sciences and Veterinary Medicine, Cluj-Napoca, Romania \\ *Corresponding author: \\ Research and Development Station for Agriculture Turda 27 Agriculturii Street, 401100, Turda, Cluj, Romania \\ Tel:+40264311680(1) \\ Fax: +40264311792 \\ E-mail:tarauadina@yahoo.com \\ http://www.doi.org/10.54574/RJPP.14.03
}

\begin{abstract}
In order to evaluate the effect of soil tillage system, fertilization and also different treatments applied to seeds on chemical composition in soybean crop, a field experiment was conducted at Research and Development Station for Agriculture Turda in 2020. Teo TD, an early soybean variety developed at RDSA Turda and registered in 2017 was used as a biological material. The compared tillage systems were: conventional tillage (plowing), reduced tillage (chisel or disk) and also no-tillage system. Four different mineral and organic fertilizers $\left(\mathrm{N}_{40} \mathrm{P}_{40}, \mathrm{~N}_{40} \mathrm{P}_{40}+\right.$ gulle, $\mathrm{N}_{40} \mathrm{P}_{40}+$ green fertilizer, $\mathrm{N}_{40} \mathrm{P}_{40}+$ gulle + green fertilizer $)$ and various treatments applied to seeds (fungicide, insecticide, fungicide + insecticide, untreated) were also studied. All data were subjected to ANOVA using Polifact. Chemical composition (protein content, oil content, stearic acid (18:0), oleic acid (18:1), linoleic acid (18:2), and linolenic acid (18:3)) of Teo TD seeds was analyzed using NIR spectroscopy. Significant differences between some tillage systems and fertilizers were recorded in protein content, fat content and also stearic, oleic and linolenic acids content. The treatments applied to seeds influenced very significant the stearic acid and oleic acid, distinct significant the linoleic acid and significant the protein content.
\end{abstract}

Key words: soybean, chemical composition, tillage, fertilization.

\section{INTRODUCTION}

Soybean (Glycine max (L.) Merril.)) is the most important and most convenient source of vegetable protein and vegetable oil known to mankind, with an importance in eradicating malnutrition, especially in developing countries (Agam et al., 2019; Idrisa et al., 2010; Pratap et al., 2011).

Being considered "the golden plant of mankind", "the miracle plant" and also "the plant of future", soybean has a great importance also in increasing the fertility of the soil, by fixing atmospheric nitrogen, being less dependent on chemical fertilizers with nitrogen (Sharifi et al., 2018; Pratap et al., 2011). Soybean oil contains unsaturated fatty acids such as oleic acid, linoleic acid and linolenic, acid with important benefits for human health (Carrera \& Dardanelli, 2017). The chemical composition of soybean seeds depends on: genotype, climatic conditions, natural soil fertility and crop technology (Muntean et al., 2014). High and high quality yields can be obtained in areas less favorable to soybean cultivation by using appropriate crop technology (Giosan et al., 1986).

Hosseini et al. (2016) describes that the tillage system was multiple advantages such as soil fragmentation, a good circulation of water and air within the soil, establishing an increased release of nutrient elements and controlling weeds. However, there are concerns about the intensive tillage uses with several environmental quality degradations and 
accelerating greenhouse gas emissions. Cassiolato et al. (2001) and Cook (2006) concluded that minimum tillage and no-tillage are the solutions to low impact on soil structure and soil biocenosis.

The influence of soybean crop technology on yield and quality is a worldwide concern. Few authors investigated the influence of tillage system, fertilization and also seed treatment on soybean harvest quality pointing out the importance of this study.

\section{MATERIALS AND METHODS}

A field polyfactorial trial with Teo TD, an early soybean variety, was performed at Research and Development Station for Agriculture Turda (RDSA Turda) in 2020. The experiment was based on a subdivided plots design with four replications. It included four soil tillage systems (S), four fertilization variants (F) and also four treatments applied to seeds (T). Average samples from each experimental variant were taken to be used for chemical analyses. Protein content, fat content and four fatty acids (stearic acid, oleic acid, linoleic acid and linolenic acid) were determined on soybean unground samples using NIR spectroscopy (Tango, Bruker Optik Gmbh, Ettingen, Germany). The three factors analyzed in the experiment are presented in the Table 1.

Table 1. Factors used for the experiment

\begin{tabular}{|l|l|l|}
\hline \multicolumn{1}{|c|}{ Soil tillage system (S) } & \multicolumn{1}{|c|}{ Fertilization (F) } & \multicolumn{1}{c|}{ Treatments applied to seeds (T) } \\
\hline Plowing (S1-control) & $\mathrm{N}_{40} \mathrm{P}_{40}(\mathrm{~F} 1-$ control) & Fungicide (T1) \\
\hline Chisel (S2) & $\mathrm{N}_{40} \mathrm{P}_{40}+$ gulle (F2) & Insecticide (T2) \\
\hline Disk (S3) & $\mathrm{N}_{40} \mathrm{P}_{40}+$ green fertilizer (F3) & Fungicide + insecticide (T3) \\
\hline No tillage (S4) & $\mathrm{N}_{40} \mathrm{P}_{40}+$ gulle + green fertilizer (F4) & Untreated (T4-control) \\
\hline
\end{tabular}

The obtained data was prepared and processed using Excel (Microsoft, USA) and also Polifact package (for ANOVA test).

\section{RESULTS AND DISCUSSIONS}

The soybean seed quality is a complex character determined by a large number of factors with a specific contribution. The destination of the soybean harvest is given especially by the protein and oil content of the seeds. Also, fatty acids are the important types of fats in the human diet, soybean having the advantage of an ideal ratio between saturated, monounsaturated and polyunsaturated fatty acids.

Table 1 shows the results for the content of protein and fat obtained from the Teo TD soybean variety in different soil tillage systems, with different types of fertilization and treatments applied to the seed. F test demonstrated that soybean protein content was very significantly influenced by the soil tillage system (S), type of fertilization (F) and also by the triple interaction between the three studied factors $(\mathrm{S} \times \mathrm{F} \times \mathrm{T})$. The treatment applied to seeds (T) significantly influenced the protein content of the seeds of Teo TD soybean variety.

With an average of $38.27 \%$ in the no tillage system, the highest protein content was obtained compared to the other 3 soil tillage systems studied. Similar results, with an increased protein content in narrow-leaved lupin seeds as the tillage system became more minimized were obtained by Panasiewicz et al. (2020) while Spoljara et al. (2009) reported significantly higher soybean grain protein contents, when more intensive tillage methods were used. 
Regarding the fat content, it seems that it is very significantly influenced by the $\mathrm{S}$ factor and by the triple interaction between the three factors analysed ( $\mathrm{S} \times \mathrm{F} \times \mathrm{T})$, while the factors $\mathrm{T}$ and $\mathrm{F}$ had an insignificant influence on this quality parameter.

Table 2. Soybean protein content and fat content in various soil tillage systems, fertilizers and treatments applied to seeds

\begin{tabular}{|c|c|c|c|c|c|c|c|c|c|c|c|}
\hline \multirow{4}{*}{$\begin{array}{l}\text { Soil tillage } \\
\text { system (S) }\end{array}$} & \multirow{4}{*}{$\begin{array}{c}\text { Fertilizer } \\
\text { (F) }\end{array}$} & \multicolumn{10}{|c|}{ Quality parameter } \\
\hline & & \multicolumn{5}{|c|}{ Protein content $(\%)$} & \multicolumn{5}{|c|}{ Fat content $(\%)$} \\
\hline & & \multicolumn{10}{|c|}{ Treatment (T) } \\
\hline & & T1 & $\mathrm{T} 2$ & T3 & $\mathrm{T} 4$ & Mean & $\mathrm{T} 1$ & $\mathrm{~T} 2$ & T3 & $\mathrm{T} 4$ & Mean \\
\hline \multirow{4}{*}{ Plowing } & F1 & 37.83 & 38.22 & 38.07 & 34.86 & 37.25 & 21.92 & 21.46 & 20.81 & 21.94 & 21.53 \\
\hline & F2 & 38.21 & 37.34 & 37.16 & 36.35 & 37.27 & 20.91 & 21.06 & 20.80 & 21.33 & 21.03 \\
\hline & F3 & 38.60 & 39.21 & 38.42 & 35.75 & 38.00 & 21.16 & 20.59 & 20.88 & 21.65 & 21.07 \\
\hline & $\mathrm{F} 4$ & 38.64 & 38.38 & 38.94 & 38.55 & 38.63 & 20.98 & 20.90 & 20.92 & 20.94 & 20.94 \\
\hline \multicolumn{2}{|l|}{ Mean } & 38.32 & 38.29 & 38.15 & 36.38 & 37.78 & 21.24 & 21.00 & 20.85 & 21.47 & 21.14 \\
\hline \multirow{4}{*}{ Chisel } & $\mathrm{F} 1$ & 37.01 & 36.90 & 37.00 & 37.64 & 37.14 & 21.92 & 22.14 & 22.40 & 21.42 & 21.97 \\
\hline & F2 & 36.76 & 34.67 & 32.38 & 31.54 & 33.84 & 20.79 & 21.18 & 21.26 & 21.63 & 21.22 \\
\hline & F3 & 36.53 & 36.25 & 36.98 & 36.22 & 36.50 & 21.89 & 21.76 & 21.49 & 21.95 & 21.77 \\
\hline & $\mathrm{F} 4$ & 37.64 & 35.53 & 36.50 & 38.79 & 37.12 & 21.72 & 21.85 & 21.97 & 20.73 & 21.57 \\
\hline \multicolumn{2}{|l|}{ Mean } & 36.99 & 35.84 & 35.72 & 36.05 & 36.15 & 21.58 & 21.73 & 21.78 & 21.43 & 21.63 \\
\hline \multirow{4}{*}{ Disk } & F1 & 37.96 & 36.30 & 37.56 & 38.58 & 37.60 & 21.31 & 22.17 & 21.87 & 21.31 & 21.67 \\
\hline & $\mathrm{F} 2$ & 32.53 & 33.50 & 34.42 & 34.84 & 33.82 & 21.58 & 20.80 & 20.78 & 20.74 & 20.98 \\
\hline & $\mathrm{F} 3$ & 37.78 & 40.18 & 39.05 & 38.31 & 38.83 & 21.10 & 21.10 & 20.92 & 21.73 & 21.21 \\
\hline & F4 & 38.58 & 38.22 & 37.33 & 37.53 & 37.92 & 20.27 & 20.52 & 21.68 & 21.58 & 21.01 \\
\hline \multicolumn{2}{|l|}{ Mean } & 36.71 & 37.05 & 37.09 & 37.32 & 37.04 & 21.07 & 21.15 & 21.31 & 21.34 & 21.22 \\
\hline \multirow{4}{*}{ No tillage } & F1 & 38.62 & 39.00 & 38.92 & 38.94 & 38.87 & 20.99 & 20.64 & 20.51 & 20.13 & 20.57 \\
\hline & $\mathrm{F} 2$ & 38.22 & 37.26 & 37.06 & 38.40 & 37.74 & 21.22 & 21.08 & 21.35 & 20.74 & 21.10 \\
\hline & F3 & 38.71 & 38.60 & 38.14 & 39.72 & 38.79 & 21.22 & 21.40 & 21.42 & 20.73 & 21.19 \\
\hline & F4 & 37.74 & 37.39 & 36.83 & 38.72 & 37.67 & 20.53 & 20.56 & 21.04 & 20.93 & 20.77 \\
\hline \multicolumn{2}{|l|}{ Mean } & 38.32 & 38.06 & 37.74 & 38.95 & 38.27 & 20.99 & 20.92 & 21.08 & 20.63 & 20.91 \\
\hline \multirow{2}{*}{\multicolumn{2}{|c|}{ F test }} & $\mathrm{S}$ & $\mathrm{F}$ & $\mathrm{T}$ & SxFxT & & $\mathrm{S}$ & $\mathrm{F}$ & $\mathrm{T}$ & SxFxT & \\
\hline & & $* * *$ & $* * *$ & $*$ & $* * *$ & & $* * *$ & ns & ns & $* * *$ & \\
\hline
\end{tabular}

In 2020, the fat content obtained at the Teo TD soybean variety had a slightly variation in the experiment, in all experimental variants exceeding 20\%. The inverse correlation between the protein and oil content is also underlined by the results obtained in the no tillage system where, compared to the protein content, the lowest average value was obtained for fat (20.91\%). A negative relationship has been also documented in the scientific literature between fat content and protein content (Burton, 1985; Haghi et al., 2012).

According to Duncan's Test (Figure 1) the soil tillage system, fertilization and treatment influenced the protein content, expressed on dry matter. The highest value was found for the soil tillage system with the disk, by fertilizing with $\mathrm{N}_{40} \mathrm{P}_{40}+$ green fertilizer and by applying a treatment with fungicide to the seeds $(40.18 \%)$. This quality parameter was significantly lower on seeds collected from the same type of fertilizer obtained on chisel system and without treatment on seed $(31.54 \%)$.

The protein content ranged: in plowing tillage system from $34.86 \%$ (F2xT4) to $39.21 \%$ (F3xT2); in chisel tillage system from $31.54 \%$ (F3xT4) to 38.79 (F4xT4); in disk tillage system from $32.53 \%(\mathrm{~F} 2 \times \mathrm{xT} 1)$ to $40.18(\mathrm{~F} 3 \times \mathrm{x} 2)$ and in no tillage system from $36.83 \%$ (F4xT3) to 39.72 (F3xT4). The soil tillage system based on disk is related to the highest range for protein content $(7.65 \%)$ while in the no tillage system was recorded the smallest variation for this parameter $(2.89 \%)$. 


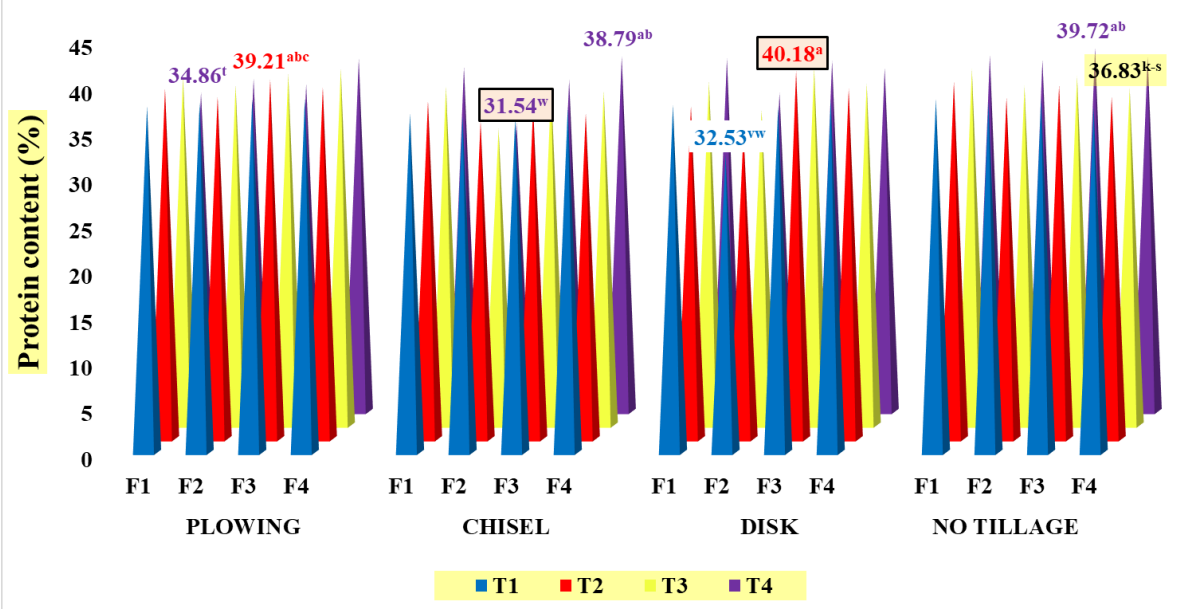

Figure 1. Effect of different soil tillage systems, fertilizers and treatments applied to seeds on soybean protein content

The fat content ranged from $20.13 \%$, in no tillage system based on $\mathrm{N}_{40} \mathrm{P}_{40}+$ gulle fertilization and without treatment to seeds, to $22.4 \%$ in the chisel tillage system with $\mathrm{N}_{40} \mathrm{P}_{40}$ fertilization and with fungicide + insecticide treatment applied to seeds (Figure 2). Even if the variation of this parameter was small $(2 \%)$ there was a trend of increasing fat content in seeds in the chisel tillage system.

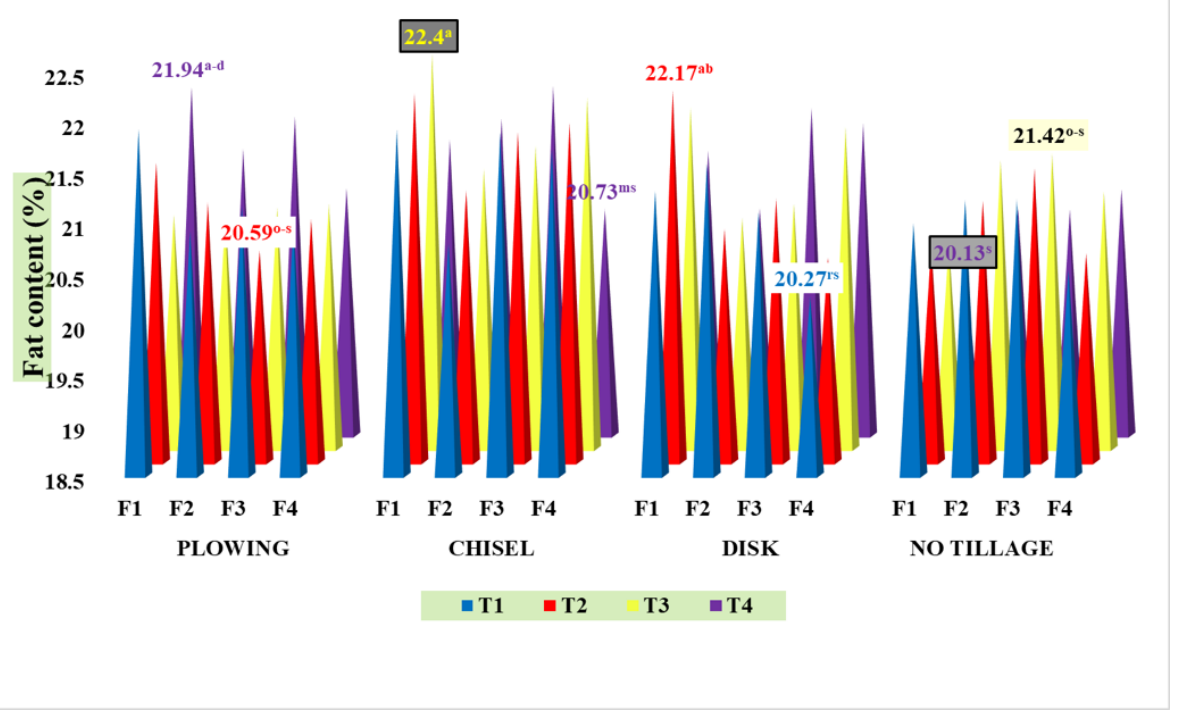

Figure 2. Effect of different soil tillage systems, fertilizers and treatments applied to seeds on soybean fat content

While the fat content was slightly influenced by the nutritional intake offered by fertilization and by the treatment applied to the seed, according to the values obtained for the $F$ test, it seems that both the stearic acid and oleic acid content are very significantly influenced by all the factors analyzed in experiment (Table 3 ). If the linoleic acid content is 
distinctly significantly influenced by the treatments applied to the seed, the linolenic acid content is significantly influenced by the soil tillage system.

Table 3. Effects of soil tillage system, fertilizer and treatment applied to seeds on protein and fat content

\begin{tabular}{|l|c|c|c|c|}
\hline \multicolumn{1}{|c|}{ Source of variation } & Stearic acid & Oleic acid & Linoleic acid & Linolenic acid \\
\hline Fertilizer (F) & $291.29^{* * *}$ & $573.71^{* * *}$ & $0.93^{\text {ns }}$ & $7.20^{\text {ns }}$ \\
\hline Soil tillage system (S) & $136.64^{* * *}$ & $21.55^{* * *}$ & $6.67^{\text {ns }}$ & $3.55^{*}$ \\
\hline Treatment (T) & $14.89^{* * *}$ & $6.0^{* * *}$ & $5.30^{* *}$ & $0.84^{\text {ns }}$ \\
\hline F x S & $268.26^{* * *}$ & $25.73^{* * *}$ & $11.63^{* * *}$ & $9.09^{* * *}$ \\
\hline F x T & $10.82^{* * *}$ & $4.34^{* * *}$ & $3.69^{* * *}$ & $3.46^{* * *}$ \\
\hline S x T & $6.25^{* * *}$ & $4.75^{* * *}$ & $3.19^{* * *}$ & $4.79^{* * *}$ \\
\hline F x S x T & $9.13^{* * *}$ & $5.40^{* * *}$ & $2.07^{* * *}$ & $2.83^{* * *}$ \\
\hline
\end{tabular}

Minimizing tillage operations (no tillage system) decreased the linolenic acid content while increased values were obtained for oleic acid content (Figure 3). The content of fatty acids, presented in Figure 3, reveal different soil tillage systems with the maximum values for the studied quality parameters: chisel showed maximum values for linoleic acid $(52.25 \%)$; disk had the maximum values for stearic acid (6.85\%) and oleic acid (25.95\%); no tillage with the maximum values for linolenic acid (4.8\%).
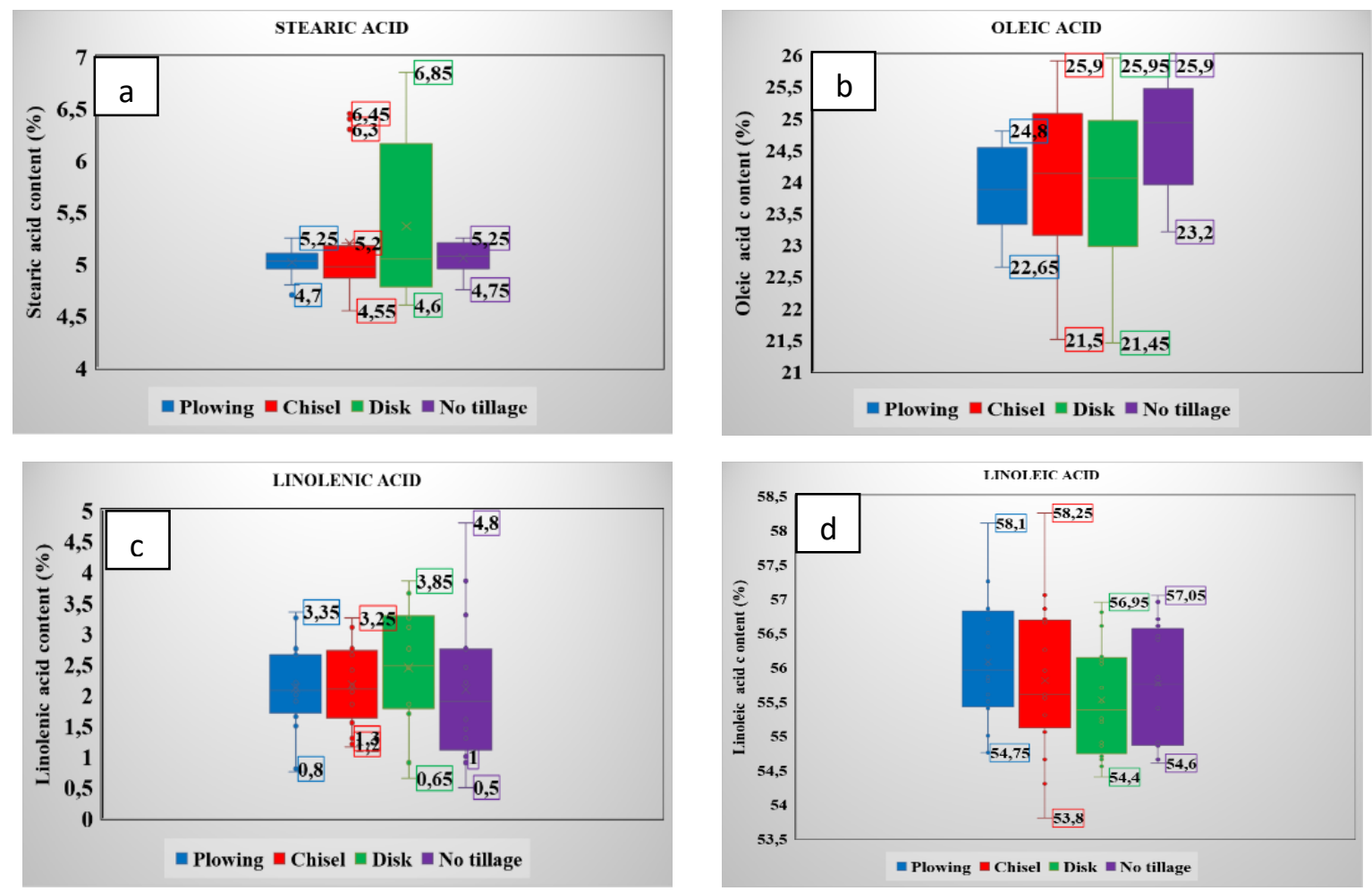

Figure 3. Effect of different soil tillage systems, fertilizers and treatments applied to seeds on soybean fatty acids (a. stearic, b. oleic, c. linolenic, d. linoleic)

\section{CONCLUSIONS}

The fat content was particularly influenced by the type of soil tillage system, with higher values in the conservative tillage systems. The fat content obtained at the early soybean variety Teo TD at RDSA Turda varied, in 2020, between $20.13 \%$ (S4xF2xT4) and $22.4 \%$ (S2xF1xT3). 
The protein content ranged between $31.54 \%$ and $40.18 \%$. Under the climatic conditions of 2020, the highest value for protein content was recorded at the disk tillage system, fertilized with $\mathrm{N}_{40} \mathrm{P}_{40}+$ green fertilizer after applying fungicide treatment to seeds. On the other hand, the untreated experimental variant, at the soil tillage system with chisel and by applying the type of fertilizer $\mathrm{N}_{40} \mathrm{P}_{40}+$ green fertilizer determined the accumulation in the soybean seeds of $31.54 \%$ protein content. In general, for protein content good results with intermediate values were obtained in the no tillage system regardless of the type of fertilization and the treatment variant applied.

While the stearic acid and oleic acid content are very significantly influenced by all the factors analyzed in experiment, the linoleic acid content is distinctly significantly influenced by the treatments applied to the seed and the linolenic acid content is significantly influenced by the soil tillage system.

The mechanisms by which fatty acids can be controlled are not well understood. Thus, by applying the right technology, good results can be obtained with respect to improved quality of soybeans and soybean oil.

\section{AKNOWLEDGEMENTS}

This research work was carried out with the support of the Romanian Ministry of Research and Innovation, CCCDI - UEFISCDI, project number PN-III-P1-1.2-PCCDI-2017-03-01/28 PCCDI/2018, within PNCDI III.

\section{REFERENCES}

AGAM, M.N., RAU, R.A., JEJURKAR, G.B., SABLE, S.B. (2019). Evaluation of the fungicides, botanicals and bioagents against Colletotrichum truncatum causing anthracnose of Soybean in pot culture. Journal of Pharmacognosy and Phytochemistry, 8, 2, 629-634.

BURTON, J.W. (1985). Breeding soybean for improved protein quantity and quality. World Soybean Research Conference III: Proceedings, 361-367.

CARRERA, C.S., DARDANELLI, J.L. (2017). Water Deficit Modulates the Relationship between Temperature and Unsaturated Fatty Acid Profile in Soybean Seed Oil. Crop Science, 57, 6, 3179.

CASSIOLATO, A.M.R., VAlPASSOS, M.A.R., ALVES, M.C., CAVALCANTE, E.G.S. (2001). Changes on a microbial activity and soil chemical properties due to different management systems. I World Congress on Conservation Agriculture, Madrid, 2, 503-507 ref. 12. Available from: https://www.cabdirect.org/cabdirect/abstract/20013178793

COOK, R.J. (2006). Toward cropping systems that enhance productivity and sustainability. Proceeding of the National Academy of Sciences of the USA, 103, 49, 18389-18394. Doi: 10.1073/pnas.0605946103

GIOSAN, N., SIN, G., NICOLAE, I. (1986). Soia. Editura Academiei republicii socialiste romania, Bucureşti, 11-20, 75-83, 187-258.

HAGHI, Y., BOROOMANDAN, P., MORADIN, M., HASSANKHALI, M., FARHADI, P., FARSAEI, F., DABIRI, S. (2012). Correlation and path analysis for yield, oil and protein content of Soybean (Glycine max L.) genotypes under different levels of nitrogen starter and plant density. Biharean Biologist, 6, 1, 32-37, 75 .

HOSSEINI, S.Z., FIROUZI, S., AMINPANAH, H., SADEGHNEJHAD H. (2016). Effect of tillage system on yield and weed populations of soybean (Glycine max L.). Scielo, The Scientific Electronic Library Online. Available from: https://www.scielo.br/scielo.php?script=sci_arttext\&pid=S0001$37652016000100377 \&$ lng=en\&tlng = en

IDRISA, Y.L., OGUNBAMERU, B.O., AMAZA, P.S. (2010). Influence of farmers socio-economic and technology characteristics on soybean seeds technology in Southern Borno State Nigeria. African Journal of Agricultural Research, 5, 12, 1394-1398.

MUNTEAN, L.S., CERNEA, S., MORAR, G., DUDA, M.M., VÂRBAN, D., MUNTEAN, S., MOLDOVAN, C. (2014). Fitotehnie, Editura Risoprint, 324-335. 
PANASIEWICZ, K., FALIGOWSKA, A., SZYMANSKA, G., SZUKAŁA, J., RATAJCZAK, K., SULEWSKA, H. (2020). The Effect of Various Tillage Systems on Productivity of Narrow-Leaved Lupin-Winter Wheat-Winter Triticale-Winter Barley Rotation. Agronomy, 10, 304. Doi:10.3390/agronomy10020304

PRATAP, A., GUPTA, S.K., KUMAR, J., SOLANKI, R.K. (2011). Soybean. Technological Innovations in Major World Oil Crops, 1, 293-321. Doi:10.1007/978-1-4614-0356-2_12

SHARIFI, S.K, LALITHA, B.S., PRAJWAL KUMAR, G.K., QASIMULLAH, R. (2018). Effect of foliar application of water soluble fertilizer on nutrient uptake and economics of soybean (Glycine max L. Merrill). International Journal of Chemical Studies, 6, 4, 2306-2309.

SPOLJARA, A., KISICB, I., BIRKASC, M., KVATERNJAKA, I., MARENCICA, D., OREHOVACKI, V. (2009). Influence of tillage on soil properties, yield and protein content in maize and soybean grain. Journal of Environmental Protection and Ecology, 10, 4, 1013-1031. 